\title{
Drivers influencing farmer decisions for adopting organic or conventional coffee management practices
}

Article

Accepted Version

Creative Commons: Attribution-Noncommercial-No Derivative Works 4.0

Bravo-Monroy, L., Potts, S. G. and Tzanopoulos, J. (2016) Drivers influencing farmer decisions for adopting organic or conventional coffee management practices. Food Policy, 58. pp. 49-61. ISSN 0306-9192 doi:

https://doi.org/10.1016/j.foodpol.2015.11.003 Available at https://centaur.reading.ac.uk/68901/

It is advisable to refer to the publisher's version if you intend to cite from the work. See Guidance on citing.

To link to this article DOI: http://dx.doi.org/10.1016/j.foodpol.2015.11.003

Publisher: Elsevier

All outputs in CentAUR are protected by Intellectual Property Rights law, including copyright law. Copyright and IPR is retained by the creators or other copyright holders. Terms and conditions for use of this material are defined in the End User Agreement.

www.reading.ac.uk/centaur 
Central Archive at the University of Reading

Reading's research outputs online 
1 DRIVERS INFLUENCING FARMER DECISIONS FOR ADOPTING ORGANIC OR

2 CONVENTIONAL COFFEE MANAGEMENT PRACTICES

3

4

5

6

7 HIGHLIGHTS

8 - Qualitative and quantitative methods were used to test drivers of coffee management

9 - Social identity, coffee institutions, and attitudes play a role in decision making

10 - Eighteen socioeconomic drivers, some with interacting effects had significant influence

11 - Technology and membership of organizations influenced adoption of organic practices

12 - Different factors rather than price premiums promote adoption of certified schemes 


\section{ABSTRACT}

Colombia is one of the world's most important producers of Arabica coffee (Coffea arabica), whose coffee-growing zone coincides with a biogeographic hotspot of biodiversity. Given that coffee agroecosystems are grown by both organic and conventional schemes of management in Santander, a region which produces coffees with specialist distinctive flavours, this study aims to better understand the factors that influence the adoption of these different schemes of management. A combination of ethnographic techniques and quantitative methods were used to examine the predominant drivers of adoption and revealed farmer perceptions associated with coffee farming, and the complexity of interacting factors, that surround their decision making. The results of qualitative analysis suggests that social identity of coffee growers, the existence of farming spaces (lived, perceived, rationalized), the influence of coffee institutions, attitudes about management practices, and social relations of production, all play an important role in the process of decision making. In quantitative terms, we identified 18 socioeconomic drivers, some with interacting effects that had significant influence on the decision to adopt either organic or conventional practices. In particular, at local scale, important factors were technology availability, the type of landowner, formal education of farmers, the role of institutions, membership of community organizations, farm size, coffee productivity and the number of coffee plots per farm. Likewise, economic drivers, such as crop profitability, determined how farmers are involved in trade and market networks at broad regional, national, and international spatial scales. By adopting a more integrated approach, combining qualitative and quantitative methodologies, we characterized the complexity of factors that influencing adoption of coffee management schemes and show that not only financial factors but also a variety of other social factors drive farmer decision making. Identifying the most influential behavioural drivers provides policy with opportunities to better support farmer livelihoods.

\section{KEYWORDS}

Coffee agroecosystems, social drivers of crop management adoption, qualitative and quantitative research, CART analysis 


\section{INTRODUCTION}

Globally the two most economically important species of coffee are Coffea arabica (Arabica coffee), a high quality coffee which constitutes over 60 percent of world production, and Coffea canephora (Robusta coffee) which is of relatively low quality compared to Arabica (ICO, 2013a). Colombia produces Arabica coffee, and has been the world's fourth largest producer after Brazil, Vietnam, and Indonesia (ICO, 2013b). In Colombia, coffee provides livelihoods for 563,000 coffee farming families of which $95 \%$ have less than 5 ha of coffee crop (FNC, 2013a). In particular, the Santander department where this study was carried out is recognized at a national level for its production of specialty coffees, namely coffees with unique flavour profiles due to particular geographic microclimates and high quality standards (FNC, 2013b).

Small-scale family farms produce over $70 \%$ of the world's coffee in 85 Latin American, Asian, and African countries; many coffee producers live in poverty and manage agroecosystems in culturally and biologically diverse regions (Bacon, 2005). Fair Trade, Rainforest Alliance and organic certifications have become an alternative for conventional coffee growers and an option to let consumers know of a product's attributes and the nature of its production (Hatanaka et al., 2005). Accordingly, the coffee farming included in this study is categorised under four different management and certification schemes:

- $\quad$ Dual certification: Fair Trade (FT) and organic (FT - Organic)

- Dual certification: Rainforest Alliance (RA) and organic (RF - Organic)

- Organic certification: It is certified but not FT or RA

- Conventional: farms use synthetic fertilisers and are not certified

Fair Trade has an emphasis on social development with goals to support democratic producer organizations, provide premiums for social development, improve labour rights, and facilitate longterm trading relationships (Valkila et al., 2010). By comparison, Rainforest Alliance schemes prioritize environmental issues on coffee agroecosystems based on the standards of the Sustainable Agriculture Network (SAN) with broader biodiversity and ecological concerns that include water quality impacts, creation of wildlife corridors, and reforestation (Barham and Weber, 2012). 
A conceptual triad of social spaces (Lefebvre, 1991) is useful to understand relationships between farmers and their coffee agroecosystems according to three dimensions, briefly recapitulated as:

- Perceived space embraces production modes and the particular locations and spatial sets characteristic of each social formation. Spatial agricultural practice ensures continuity and some degree of cohesion. It embodies a close association between daily routine and rural reality.

- Conceptualized space is a conceived space by scientists or planners, and is delineated by both knowledge and power, e.g. the territorial ordering designed by technocrats without considering cultural differences at regional or local scales.

- Lived space embodies associated images and symbols such as religion or art signs. This space embraces places and their symbolic value.

The analysis of drivers of coffee management can be conceptually based on the new ecological anthropology postulated by Kottak (1999), who recognizes the importance of larger scale. Here the focus is no longer the local agroecosystem, but the intersection of global, national, regional, and local actors, studying the outcome of the interaction of multiple levels and multiple factors. Some ideas from ecological history discussed by Cronon (1985) involve changes in the way people create and re-create their livelihood in terms of changes, not only in their social relations, but in their ecological ones as well. The dominance of neoliberalism and globalisation have brought more and more people into trade and market relations which lie well beyond the boundaries of their local ecosystems.

Studying the drivers of coffee management adoption entails an understanding of social, political, economic, demographic, technological, cultural and biophysical factors that directly or indirectly influence decisions at the coffee agroecosystems scale. The core of the approach is to use the understanding of social factors at the farm level to provide better insight in what processes are important in the decision making process of a management adoption (Overmars and Verburg, 2005). 
In the context of coffee agricultural practices in Colombia, the adoption of integrated pest management has been associated with education level and the wealth of the farmer as predominant factors (Chaves and Riley, 2001); likewise, the introduction of the "Caturra" coffee variety was linked to factors such as an increase in demand for labour, need for cash inputs, especially fertilizer and hired labour, and risk avoidance behaviour (Stabile et al., 1984). The role of coffee institutions has been important for the intensification of coffee crop production since 1970, when the threat of coffee rust was a critical factor in production (Guhl, 2008). Coffee intensification gave rise to a decrease on coffee crop areas, a reduction on shaded coffee farms and pastures zones as well as increase on other crop areas (Guhl, 2008).

A number of studies have assessed the influence of coffee certification on profits using survey data collected from coffee growers. For example, several have compared Fair Trade and organic cooperative membership with conventional farming (Arnould et al., 2009; Barham et al., 2011; Beuchelt and Zeller, 2011; Bolwig et al., 2009; Méndez et al., 2010; Valkila, 2009). Although these studies vary in terms of the criteria used to measure returns (e.g. prices, productivity, profits, with and without labour costs included), most of them conclude that there are relatively limited price gains and income improvement linked to these certification schemes compared to conventional coffee management. Similar conclusions have been drawn from studies conducted in Mexico and Peru (Barham and Weber, 2012) which have contrasted conventional, Fair Trade/organic, and Rainforest Alliance schemes and have revealed that yields, rather than price premiums, are most important for increasing net cash returns for coffee growing households. This suggests that certification norms that permit the improvement of yields are essential for improving grower welfare and attracting and maintaining growers to these schemes.

A study in Nicaragua (Valkila et al., 2010) showed that although Fair Trade provides price premiums to producer organizations, a larger share of the retail prices remains in the consuming country (in this case, Finland) relative to conventional coffee trade. Paradoxically, although certified farmers and cooperatives in producing countries do receive some benefits, Fair Trade principally empowers roasters and retailers in consuming countries due to the fact that they are able to charge significantly higher margins for Fair Trade coffees than for conventional coffees. The 
premiums paid by Fair Trade consumers, the ethical donations, were found to largely remain in Finland and therefore Fair Trade appears to be an ineffective way of transferring benefits to producer countries. In this way, the rise of specialty coffee market might parallel to a certain extent the global trend by which a high percentage of the coffee market is recently controlled by a few largest roasters (Topik, 2008). The latter can be best understood in the broader historical context of the creation and development of coffee commodity chains. It involved over time multiple connections between production, intermediation, processing, marketing, and consumption.

Governance of the chain moved away from the grower to the exporter in the sixteenth century; to the roaster, governments and international institutions in the twentieth century; and today to a few multinational firms (Topik, 2008).

A study conducted in Costa Rica (Wollni and Brammer, 2012) that analysed the 'drivers' that encourage farmers to opt in to certification schemes found that experience in coffee cultivation, more education, larger farms and a pre-existing association with a coffee cooperative were all relevant and positive factors. Farmers might be particularly attracted by the additional income activities that an organization assists with as a safeguard for periods of low coffee prices. On the other hand, a study of the adoption of Fair Trade organic schemes in Mexico revealed that the availability of family labour, liquidity, and location were more likely to affect the decision to go organic (Weber, 2011). One of the most important factors determining whether farmers choose to opt in to a certification process is the functioning of producers' organisations. This was confirmed in the Costa Rican study (Faure et al., 2012).

On the other side, prior studies (Press et. al., 2014) have suggested the role of contending ideologies in restricting the transition from conventional farming to organic wheat production in industrial scale agriculture. Despite evident economic incentives in the High Plains region of North America, barriers to adoption stemmed from (i) ideological conflicts e.g., chemical farming norm is strongly appreciated and rooted in the region; chemical wheat production receives government subsidies, which organic producers do not receive; (ii) struggles for legitimacy among farmers within a market e.g., conventional farmers may refer to the structures of regulatory legitimacy such as input suppliers, banks, insurers, and various federal agencies. Organic farmers, however, may 
draw on themes of cultural legitimacy to defend their on farm management practices such as innovation, work in harmony with nature and evoke the traditions of their forbearers; and (iii) the function of supporting institutions in building regulatory legitimacy e.g., structural barriers to changing orientation such as organic input supply issues, transportation and storage problems, and challenges of finding a buyer.

While there have been a number of quantitative studies on the factors driving adoption of specific crops (e.g. Mazvimavi and Twomlow, 2009) and certified coffee (e.g. Weber, 2011), this study combines quantitative and an in-depth qualitative analysis to provide a better understanding of the complexities in the decision making processes. By adopting a more integrated approach, this research aims to improve our understanding of the complex interactions of factors that influence the adoption of particular coffee management schemes. This study focuses on the following key questions: (1) what are the predominant drivers for adopting either organic or conventional management? (2) What are the most significant perceptions of coffee growers in relation to this decision? (3) What is the the likelihood of farming adoption?

\section{METHODS}

\subsection{Study area and data collection}

The study was conducted in Ocamonte, Pinchote and EI Valle de San José, three towns of the Santander area, a mountainous region where a high proportion of Colombian specialty coffees are produced. Data collection combined qualitative and quantitative approaches as an appropriate methodology for this research. Firstly, a qualitative view in Ocamonte allowed for the capture of indepth, ethnographic detail that is considered essential for understanding farmers' management decisions. Secondly, the quantitative procedure included a survey of 134 farmers (30 organic and 30 conventional in Ocamonte, 27 organic and 30 conventional in El Valle de San José, 10 organic and 7 conventional in Pinchote). The survey sample in three towns included small-scale coffee farmers, a fact that is common in Colombian coffee-growing regions. Accordingly, the 67 organic farms had an average size of $7.12 \pm 1.0$ (SE) ha and the 67 conventional farms had an average of $3.41 \pm 1.0$ (SE) ha. In Ocamonte, where ethnographic research was conducted the average size of organic and conventional farms was $4.3 \pm 0.7$ (SE) ha and $1.2 \pm 0.3$ (SE) ha respectively. A survey 
covered family characteristics, ownership, manual labours and agricultural practices, coffee production costs, yield, income, available infrastructure, social relations of production and interactions with institutions. Given that qualitative information was collected before the survey, it allowed a familiarization with local terms and the identification of preliminary drivers of management adoption which enriched the design of survey. Afterwards, ethnographic information permitted a general contextualization of socioeconomic quantitative data. Therefore survey data from three communities was used to complement the data collected from a small sample of farmers who participated in in-depth interviews, meetings, agricultural practices, sales or informal dialogues, in such a way that fifty potential drivers of management adoption were identified.

\subsection{Qualitative methods}

Assessing and identifying factors of decision-making processes at farm level may require interaction with subjects, and a nuanced reading of human expression and use of language (Frank et al., 2011). Qualitative methods used on a small sample for exploratory analysis are useful for this purpose. Three variables were analysed: perceptions of land-use, management practices, and the role of institutions in the selection of a land management method. Ethnography was used for gathering empirical data aimed at describing the nature of people (Guber, 2001) in relation to these variables. It consists of the processes and products of research that documents what people know, feel, and do in a way that places those phenomena at specific times in the history of individual lives, including pertinent global events and processes (Guber, 2001; Handwerker, 2002).

Three ethnographic methods were considered: firstly first-hand observation of daily activities (participant observations) related to coffee management practices, coffee farmer meetings and purchases at sale points; secondly, semi-structured interviews with 14 small-scale coffee farmers in Ocamonte. The interview protocol was designed to collect detailed qualitative information on themes related to beliefs and attitudes about coffee farms and management practices, and the role of institutions (banks, coffee institution, certification agencies, farmer's cooperatives) on management adoption and land-use. Questions were flexible in the sense that farmer could provide further explanation in case of responses with pertinent information. Eight of the interviewed farmers were members of a cooperative and produced organic coffee; six were non-members and 
grew conventional coffee. To triangulate institution-related data reported by member-farmers, two coffee organization leaders and one agronomist were also interviewed. The interview texts were qualitatively categorized and coded to identify key themes relating to drivers of coffee management adoption and potential relationships between interview data variables. Thirdly, informal dialogues with farmers, other technicians, and local market agents in Ocamonte and neighbouring towns were carried out. With this methodological triad, findings from detailed farm observations of what farmers are doing, why, and with what effect were identified on the decision of whether to opt into a certification scheme.

\subsection{Quantitative method}

A questionnaire was developed to obtain detailed information on field management practices, crop yields and social relations of production. Questionnaire design, question content and question wording were defined and decided based on ethnographic information gathered previously. A format using tables was adapted from household surveys designed by the World Bank (World Bank, 2009).

Given that there were only 67 organic farms with a certification seal (Fair Trade organic, Rainforest organic, solely organic) on this region at the time of survey, the location of organic farms determined the selection of the 67 conventional farms. Taking into account the Colombian territorial organization of farms in "veredas" - each "vereda" groups several farms - conventional farms were chosen according to their belonging to the same vereda where organic farms were located, in order to have similar environmental conditions. Based on this survey, drivers that influenced the selection of organic and conventional coffee management systems were analysed.

\subsection{Data analysis}

Fifty potential drivers previously identified from ethnography and survey were analysed with nonparametric Chi-square and Kruskal-Wallis methods in order to identify factors with significant effects on management. These statistical analyses were performed using the software GenStat ( $11^{\text {th }}$ edition). The Chi-square tests were used to test the statistical significance of the association between drivers and the type of management. The significance of the impact of drivers associated with coffee productivity, production costs, incomes and profitability was tested by means of the 

Kruskal-Wallis method. From the fifty possible drivers originally identified, nineteen drivers (Table 1) were grouped as social, institutional, location and market factors, were identified as the most significant driving forces that were likely to have influenced the selection of organic and conventional coffee management systems. Social factors include details that are relevant for understanding farmers' context of crop management adoption (e.g. education, membership of collectives). Location factors involve characteristics of farmers (e.g. land owner), and farm attributes (e.g. farm size, technology availability, productivity, costs) that are particular to a farm and that are useful in understanding the processes of management adoption. Institutional drivers comprise institutions and their strategies (e.g. credits, incentives, assistance) with influence in shaping decisions of farmers. Finally market drivers add economic factors of relevance on making decision processes (e.g. profitability, income, satisfaction with prices).

Table 1 - Drivers selected as the most significant factors

\begin{tabular}{|c|c|c|c|}
\hline INSTITUTIONAL & SOCIAL & $\begin{array}{l}\text { LOCATION } \\
\text { FACTORS }\end{array}$ & MARKET \\
\hline $\begin{array}{l}\text { 1. Technical assistance } \\
\text { 2. Number of contacts with } \\
\text { technicians in } 12 \text { months } \\
\text { 3. Participation on meetings } \\
\text { 4. Satisfaction with } \\
\text { institutional incentives }\end{array}$ & $\begin{array}{l}\text { 1. Membership of } \\
\text { community } \\
\text { organizations; } \\
\text { benefits received as } \\
\text { member of community } \\
\text { organizations; } \\
\text { satisfaction with } \\
\text { incentives } \\
\text { 2. Population density } \\
\text { 3. Years of formal } \\
\text { education } \\
\text { 4. Learning method }\end{array}$ & $\begin{array}{l}\text { 1. Coffee productivity: } \\
\text { Kg per ha; } \\
\text { cargas }^{a} \text { per ha } \\
\text { 2. Production costs: } \\
\text { Pesos per carga; } \\
\text { USD per carga } \\
\text { 3. Land owner } \\
\text { 4. Number of coffee } \\
\text { Plots } \\
\text { 5. Farm size } \\
\text { 6. Technology availability } \\
\text { 7. Off-farm job }\end{array}$ & $\begin{array}{l}\text { 1. Coffee dependence: } \\
\text { percentage of total } \\
\text { income from coffee } \\
\text { 2. Satisfaction with sale } \\
\text { Prices } \\
\text { 3. Profitability } \\
\text { 4. Income per carga: } \\
\text { Pesos per carga; } \\
\text { US } \$ \text { per carga }\end{array}$ \\
\hline
\end{tabular}

Classification and Regression Trees (CART) was used in order to estimate the probability of a farmer adopting organic or conventional practices based on a number of drivers of farmers' decision-making. The basic algorithm underlying CART is to repeatedly partition a data set into more and more homogeneous groups, using variance minimizing algorithms to determine the most parsimonious tree. The output is represented graphically as a dichotomous tree that is relatively easy to interpret (De'ath and Fabricius, 2000; Williams et al., 2009; Zheng et al., 2009). The analysis was performed using the software Salford Predictive Miner (version 6.6). Following and adapting the approach of Williams et al. (2009), optimal models were found by examining trees for four factorial combinations of drivers, social (six variables), institutional (six variables), location 
(seven variables), and market (five variables) that maximized the proportion of variance explained.

Optimal sized models were based on relative error values, having established that relative error can range between 0 and 1 , with lower values indicating better performance.

Initial CART analysis resulted in very large trees which were pruned back to an optimal sized tree based on relative error rates. Potential overfitting of tree models can be avoided with the small size of the trees since smaller trees are often highly accurate models (Steinberg and Golovnya, 2006). Collinearity between variables commonly hinders statistical analyses, frequently making it difficult to precisely estimate the distinct effect of a particular independent variable on a dependent variable of interest (York 2012). CART presents an approach to handling collinearity: the analysis allows only one of any set of correlated variables to enter the model at any given split, which prevents the model from including correlated variables. As CART splits the data into progressively smaller groups in fitting the tree, the collinearity among predictor variables may change, and variables that could be highly correlated across all the data may be less so in subsets of the data (Ferraro et al., 2009).

\section{RESULTS}

\subsection{Qualitative assessment}

\subsubsection{The identity of coffee growers}

Identity is a powerful organizing presence in social life, in the sense of belonging to sociable recognizable corporate groups (Leve, 2011) and farmers in this study illustrate the weight of social identity. For instance, most of farmers responded "all my life" when asked how long they have been growing coffee. Thus coffee farming has been an activity and identity passed down through generations. People not only live from coffee but also with coffee whose high quality gives prestige and recognition when they sell their production. Two farmers stated: "This is the art we know..." and [Coffee is] "the best future we have sown...". Coffee growing is more than a productive labour, is an activity through which farmers express ideas, dreams and expectations. The collective character of this activity is also frequent in speech since they use "we" instead of "I", pronouns which can be indicative of social group association. However, according to ethnographic information, it is often that young generations - who are sons/daughters of coffee farmers - have 
migrated to urban spaces in search of higher education, different jobs, even to enrol in the army. That behaviour represents a matter of growing concern since impacts the relief for the coffee cultivation. It is noteworthy that parents have certain responsibility on this attitude since they frequently allude to "better conditions for future of children than those we have to live". There may, therefore, be a fracture between current farmers and their descendants with consequences for continuity in the future of coffee farming.

\subsubsection{Perceptions of coffee farm spaces and surrounding environments}

In order to better understand perceptions it is important to place them in a theoretical framework that helps to understand relationships between farmers and agroecosystems. For this we have used the work of Lefebvre (1991) that describes a conceptual triad of social space.

Firstly, a space as directly lived in farms that are seen as sacred spaces where religious symbols are part of the coffee plots. For instance, religious symbols connected with the Catholic Church (e.g., crosses of different size with or without flower ornamentation) are put on the coffee fields especially at early phases of growth plantation in order to entrust its prosperity to God. On the other hand, during prolonged dry conditions, a priest can perform religious ceremonies in the farms aimed to achieve that the rain comes to the zone. There are terms that describe the sacral character of land including "land is a great God blessing", "land is primordial, is everything", is "our life", "is like a woman, a mother who has to be cared for", "the biggest treasure". The implications of those perceptions allow to understanding why and with what effect on the farm people are doing actions. According to some farmers, to reach a high level of organic production requires dedication, hard work and almost devotion to farms, e.g., organic agricultural practices that favour the nourishment for the soil and coffee plant roots, regular management of shade especially at the starting period of the crop, inter alia. In line with this, some farmers who apply organic practices expressed a sacred relationship with land, and rejected actions such as the use of herbicides on nearby farms with sugarcane crops. In more general terms, older farmers and coffee landscapes are very closely related and stories are attached to particular places e.g., the health of the land and that of the forebear people are closely intertwined. The history of coffee growers is described and revealed in their land usage. 
Secondly, a pragmatic space embodies the daily experiences and routines. Coffee farming is perceived in utilitarian terms by virtue of fruit production, people's occupation, and economic returns for family wellbeing. Land which produces coffee can thus be more appreciated than other land-uses. Forest is in essence associated with coffee crops and is valued particularly for its ability to shade coffee plants. Coffee areas have become fragmented as they have been passed from parents to children by property inheritance or purchasing: farm sizes have been reduced and it is likely that family groups are neighbours with different ties of kinship. At the same time, farmers have also increased their crop areas because coffee profits have allowed the acquisition of new plots. Hence the coffee space is dynamic and changing.

Finally a rationalized and more instrumental space conceived by members of the coffee institute and certification agencies. The origin of shade grown coffee by small scale farming can be traced to the 1960s in the study area. The coffee institute has played a key role in increasing the area of growth by providing extension programs to farmers aimed to improve local agricultural practices. Representatives of Fairtrade labelling organization arrived in the region in 1994 by means of the coffee institute. Conventional coffee was purchased under Fairtrade (FT) certification once a farmers' cooperative was legally constituted. The arrival of FT did not generate significant changes in the usual manner of farming coffee since conventional management of crops easily satisfied rules in compliance with FT standards. The benefit of FT for farmers become to manifest around 2002 when international coffee prices fell to extreme low values and the cooperative received an important amount of money to compensate that situation. Those resources were heavily invested in different improvements at local and farms levels (e.g., housing, post-harvest processing of coffee, roads).

In parallel with that situation from 2002 onwards, a FT certifier initiative for farming under organic conditions was suggested to local producers. However, their transition to organic was certainly hard for most farmers because it altered their farming practices with effects on their agricultural spaces and daily routines e.g., paperwork; introduction of new wastewater treatments and compost making process; emphasis on rigorous screening during post-harvesting process; coffee was planted using better arrangements of plots; strict separation of sugarcane plots with hedges to 
protect coffee plantations against possible effects of very specific chemical inputs that were allowed to use in that plots; recycling of materials; increased reforestation especially along the border of water streams. From farmers' perspective one of the most important consequences of adopting organic management was the decline in the amount of yield during the period of transition (up to three years) to get the certification. Despite benefits received, that reduction apart from farm requirements have discouraged new farmers to opt for organic management.

For a few farmers, however, transition was not as drastic. They had been applying manure and mulch/wastes of sugarcane processing without using synthetic fertilisers. Thus, adopting a new orientation was not as difficult for them.

In this way, institutional priorities gave rise to the improvement in farmer life quality and the manner in which they cultivated coffee, especially in the first decade of the twenty-first century. Thus an active role of space, as supplementary knowledge and action, became operational in the construction of a particular mode of production: farms that yield certified organic coffee.

Further, in line with Strand et al.'s (2014) results, through management decisions and ultimately the process of creating their coffee fields, farmers strengthen their identities through day-to-day activities in their material world. For instance, a farmer indicates: "new systems of waste water treatment arose when we became organic"; similarly, other farmer expresses "We, the organic farmers, receive additional training".

\subsubsection{Attitudes about management practices}

In accordance with farmers view, organic farms require the involvement of more days of work, dedication and care compared to conventional farms, especially during the initial stages of coffee crop. The duration of the production phase on conventional plants may be longer than organic crops. Coffee production is lower on organic than conventional schemes. However, the use of organic minerals alongside organic manure may increase the level of yield; the application of minerals has been practiced in some farms since 2006. The use of shade cover may depress coffee production if it is more than $50 \%$ since it may delay cherry maturation. In comparison, there is a relevant role of shade in reducing the use of certain fertilisers through deposition of leaf litter. 
Additional effects of adopting organic schemes on the daily lives and practices of farmers include the change of emphasis from oral tradition to written records of practices. Since organic certification arrived at zone, all coffee activities and involved finances must be recorded, which has caused certain difficulties due to the time spent on this task and the fact that detailed writing has not been a habit.

\subsubsection{The role of the coffee institute}

According to ethnographic information, the role of the coffee institute involves both a channel intermediary in the marketing system and a farming institute in rural and policy life. Sometimes that performance has been a controversial issue at local and national levels taking account of its participation as market competitor/trader, regulator of bean quality standards, policy maker and promoter of not only coffee farming but also of the national union of coffee growers. From a historical perspective, that institute was the only one that survived after most coffee-growing countries abated their coffee organizations with the dissolution of the International Coffee Agreement in 1989 (Topik 2008).

As a result of multiple roles, several events have taken place: the establishment of coffee crops with commercial purposes; technical assistance by means of agricultural extension services; investment of coffee sales in infrastructure; the introduction of certification seals; and trade of coffee at international level. In all, this has had effects on the landscape with the promotion of organic and conventional schemes of management, whose growing demand for market has been a factor of land-use change.

In this context, the coffee institute has had a strong influence as advisory agent on the decisionmaking of farmers to opt for certified organic schemes since it facilitated the entry of Fair Trade (FT) into Santander region. This took place in 1994 when a meeting was promoted to connect representatives of Fair Trade organization, a trader, and coffee growers of the zone. Around 2008 the coffee institute assumed also the role of trader of FT coffees as part of its mission to export specialty coffees (including organic coffees of different seals as Rainforest Alliance (RFA)). As a result, the coffee institute also became a competitor as others traders, taking part in the race to export certified and conventional coffees. The fact to assume a role as trader of FT and RFA in the 
region had economic repercussions on the net value of premium offered to organic farmers because from an institutional perspective, there was an interest to equate premiums offered to organic production under FT with RFA. As a result and contrary to farmer expectations, there was not a large distinction between premiums of FT and RFA seals as happened during the coffee crisis in 2001/2002, and therefore the economic incentives to grow organic coffee did not resulted in better situation for organic farmers under FT certification. In the face of such circumstances, some farmers opted for certification seals whose requirements allow the use of certain agrochemicals.

Thus, the type of certification seal is relevant at local level since Fair Trade (FT) prioritize better prices and working conditions, and Rainforest Alliance (RFA) gives pre-eminence to conservation efforts based on standards for Sustainable Agriculture (e.g., wastewater treatment, protection of wildlife). In terms of work habits, there are several FT requirements that had to be fulfilled by farmers at the moment of the field work of this study; inter alia, avoiding child labour and the accomplishment of cooperative projects aimed to improve the well-being of farmers. Those project aims - even those designed to favour coffee yields - are based on democratic decisions making since cooperatives receive the FT certification. FT is open to small farmer organizations which must be owned and governed by themselves. In practice there are subtle differences in the way those conditions are satisfied: farmer organization decisions are strongly influenced by the coffee institute; the subject of child labour often collides with local tradition of teaching coffee agricultural practices to children, which has also an impact on the relief for the coffee farming; the involvement of board members takes time and effort which affects their dedication to daily agricultural tasks.

Producer organizations are paid a FT minimum price for washed Arabica or the market price if higher. Farmers who have currently Fair Trade or Rain Forest Alliance with organic certification believe to receive a significantly higher sale price as compensation for low level of production and the dedication of farmers. Unfortunately, the final payment they receive in net cash does not always correspond to their expectations. Fair Trade certifications provide a minimum price to farmers and a social premium to cooperatives; however this study observed that these premiums did not necessarily translate into higher incomes for farmers. Distinction between FT and RFA 
certifications was particularly evident during the coffee crisis in 2001/2002 when coffee prices fell to an extreme low of US $\$ 45$ cents per pound. During this time only Fair Trade farmers received the highest value of monetary premium to compensate the extremely low price. Thus, international low prices highly favour growers with FT seal.

\subsubsection{Social relations of production}

In general terms, current coffee farmers are from the 45 to 70 year age bracket and most of their children study and contribute little to coffee and agricultural work. Young people generally prefer living in nearby towns or distant cities in order to study or work. The perceptions reveal a dichotomy of visions - urban life where study and other jobs are possible or rural life with no such options - and this has consequences such as a shortage of coffee pickers during harvest and a low level of generational change that encourages continuity of coffee farming.

On the other hand, the coffee harvest is enriched by the principle of 'reciprocity', and facilitated by exchanges of tasks between family members or neighbours. Communal work relations are common and coffee has generated equity in terms of benefits to everybody, owners and workers. There is a gender division of labour on conventional farms, whereby men tend to specialise in coffee work within the local area, and women tend to specialise more in unpaid coffee work within the family farm. By contrast, where crops are farmed organically, it is common for spouses to work together, growing coffee within their own small farm. Relations between age groups around coffee farming are common since it is usual that women and aged people partake in meetings related to farmer's cooperative. Spouses work together on farm and wives administer home finances with coffee profits, and ensure food provision. Off-farm employment is common on conventional farms for husbands and adult children.

Cooperatives of coffee farmers offer important benefits to members as access to information, training, coffee commercialization, and projects aimed to improve health, education, or production. Farmers express the relevance of meetings to improve agricultural practices or adopting certified schemes of farm management. 


\subsection{Quantitative assessment}

3.2.1 Drivers of coffee crop management choice

Statistically significant associations between social factors and a crop management type were found for the farms surveyed in three communities of Santander. Table 2 shows the results of the analysis of significance between the different types of social drivers and the management type.

This table shows the results that had a significant effect on a crop management category. The Chisquare test is significant at 0.001 level, indicating a strong association between a crop management and specific factors. For instance, the benefits received from membership of community organizations $\left(\chi^{2}=39.9, \mathrm{P}<0.001\right)$ and the availability of technology $\left(\chi^{2}=76.4, \mathrm{P}<\right.$ 0.001). Other important factors include the learning method of coffee agricultural practices, population density and benefits received of community organizations. It is interesting to note that coffee growers have learnt organic coffee production by themselves including learning from their parents, and also by training sessions on meetings with institutional assistance. By contrast, conventional farmers have learnt mostly by themselves. Smaller population density is common on organic farms compared to higher number on conventional schemes. All organic farmers are members of community organizations, although this is expected because organic certification for small farmers operates through groups.

A highly significant relationship $(P<0.001)$ between coffee management and location factors was also found, such as technology availability, the nature of land ownership, farm size and the number of coffee plots per farm. In this regard, the existence of adequate technology, married couples as land owners, more than six coffee plots per farm, and more than five ha of farm size were common on organic farms. In contrast to the farmer perceptions, higher values of coffee productivity $(P=$ $0.004)$ and smaller values of coffee production costs $(P=0.003)$ were associated with organic farms. By comparison, farms with high off-farm employment $(P=0.002)$, basic technology, only one owner (husband or wife or other family member), less than five coffee plots per farm, and less than five ha of farm size were all associated with conventional management of coffee farms. 
513 Institutional factors were also associated $(P<0.001)$ with organic farms such as enough technical 514 assistance, a higher number of contacts with technicians or agronomists, full participation in 515 meetings and satisfaction with incentives offered by the coffee institution. Conversely, insufficient 516 technical assistance, smaller contacts, minor participation and dissatisfaction with incentives were 517 related to conventional farms. Market factors such as a major dependence on coffee incomes were 518 associated $(P<0.001)$ with organic farmers, who expressed more dissatisfaction with prices 519 offered despite higher levels of both profitability and incomes. In comparison, less dependency, 520 more satisfaction with prices, and smaller profitability were associated with conventional coffee 521 growers.

522 
Table 2 - Analysis of significance between social factors and the type of coffee crop management in three communities of Santander

\begin{tabular}{|c|c|c|c|c|c|}
\hline \multirow[b]{2}{*}{ DRIVERS } & \multirow[b]{2}{*}{ DRIVER CATEGORIES } & \multirow{2}{*}{$\begin{array}{c}\text { ORGANIC } \\
\text { FARMERS } \\
(n=67)\end{array}$} & \multirow{2}{*}{$\begin{array}{c}\text { CONVENTIONAL } \\
\text { FARMERS } \\
(n=67)\end{array}$} & \multicolumn{2}{|c|}{ CHI-SQUARE TEST } \\
\hline & & & & $\begin{array}{l}\text { Chi-square } \\
\text { value }\left(\chi^{2}\right)\end{array}$ & $P$ value \\
\hline \multicolumn{6}{|l|}{ SOCIAL FACTORS } \\
\hline $\begin{array}{l}\text { Years of formal } \\
\text { Education }\end{array}$ & $\begin{array}{l}0 \text { to } 5 \text { years } \\
6 \text { to } 16 \text { years }\end{array}$ & $\begin{array}{l}50 \\
17\end{array}$ & $\begin{array}{c}59 \\
8\end{array}$ & 4.06 & 0.044 \\
\hline Learning way & $\begin{array}{c}\text { Independent experience } \\
\text { Coffee institution } \\
\text { Both } \\
\end{array}$ & $\begin{array}{c}31 \\
4 \\
32 \\
\end{array}$ & $\begin{array}{c}47 \\
8 \\
12 \\
\end{array}$ & 14.1 & $<0.001$ \\
\hline \multirow{3}{*}{$\begin{array}{l}\text { Membership of } \\
\text { community } \\
\text { organizations } \\
\text { Benefits received with } \\
\text { membership } \\
\text { Incentive satisfaction }\end{array}$} & $\begin{array}{l}\text { Membership } \\
\text { No }\end{array}$ & $\begin{array}{c}67 \\
0\end{array}$ & $\begin{array}{l}45 \\
22\end{array}$ & 34.85 & $<0.001$ \\
\hline & $\begin{array}{c}\text { Only training } \\
\text { Training, credits, inputs, money } \\
\text { No benefits }\end{array}$ & $\begin{array}{c}28 \\
39 \\
0\end{array}$ & $\begin{array}{l}26 \\
18 \\
23 \\
\end{array}$ & 39.88 & $<0.001$ \\
\hline & $\begin{array}{l}\text { Full satisfaction } \\
\text { Conformity }\end{array}$ & $\begin{array}{l}56 \\
11\end{array}$ & $\begin{array}{l}44 \\
23\end{array}$ & 5.77 & 0.016 \\
\hline Population density & $\begin{array}{l}\text { Between } 0.07 \text { and } 6 \text { persons/ha } \\
\text { Between } 6 \text { and } 60 \text { persons/ha }\end{array}$ & $\begin{array}{c}64 \\
3\end{array}$ & $\begin{array}{l}46 \\
21\end{array}$ & 18.14 & $<0.001$ \\
\hline \multicolumn{6}{|l|}{ LOCATION FACTORS } \\
\hline $\begin{array}{l}\text { Technology } \\
\text { Availability }\end{array}$ & $\begin{array}{c}\text { Basic } \\
\text { Adequate }\end{array}$ & $\begin{array}{c}9 \\
58\end{array}$ & $\begin{array}{l}57 \\
10\end{array}$ & 76.4 & $<0.001$ \\
\hline Land owner & $\begin{array}{l}\text { Husband } \\
\text { Married couple } \\
\text { Wife, other }\end{array}$ & $\begin{array}{l}40 \\
17 \\
10\end{array}$ & $\begin{array}{c}39 \\
1 \\
27\end{array}$ & 25.35 & $<0.001$ \\
\hline Coffee plots number & $\begin{array}{l}1 \text { to } 5 \text { plots } \\
6 \text { to } 10 \text { plots } \\
>11 \text { plots }\end{array}$ & $\begin{array}{l}26 \\
27 \\
14\end{array}$ & $\begin{array}{c}55 \\
11 \\
1\end{array}$ & 31.01 & $<0.001$ \\
\hline Farm size & $\begin{array}{l}<5 \text { ha } \\
5 \text { to } 10 \text { ha } \\
>10 \text { ha }\end{array}$ & $\begin{array}{l}37 \\
16 \\
14\end{array}$ & $\begin{array}{c}57 \\
8 \\
2\end{array}$ & 17.13 & $<0.001$ \\
\hline Off-farm job & $\begin{array}{l}\text { Yes } \\
\text { No }\end{array}$ & $\begin{array}{l}28 \\
39 \\
\end{array}$ & $\begin{array}{l}46 \\
21 \\
\end{array}$ & 9.91 & 0.002 \\
\hline \multicolumn{6}{|c|}{ KRUSKAL-WALLIS TEST } \\
\hline Coffee productivity $(\mathrm{kg} / \mathrm{h}$ & & $974.8 \pm 90.4$ & $680.3 \pm 72.2$ & & 0.004 \\
\hline Costs (US\$/125 kg) & & $295.5 \pm 43.6$ & $417.8 \pm 46.1$ & & 0.003 \\
\hline \multicolumn{4}{|c|}{ INSTITUTIONAL FACTORS } & \multicolumn{2}{|c|}{ CHI-SQUARE TEST } \\
\hline Technical assistance & $\begin{array}{l}\text { Enough } \\
\text { Insufficient }\end{array}$ & $\begin{array}{c}65 \\
2\end{array}$ & $\begin{array}{l}44 \\
23\end{array}$ & 24.79 & $<0.001$ \\
\hline $\begin{array}{l}\text { Contacts with } \\
\text { agronomists on last } \\
\text { twelve months }\end{array}$ & $\begin{array}{l}0 \text { to } 5 \text { contacts } \\
6 \text { to } 12 \text { contacts }\end{array}$ & $\begin{array}{l}48 \\
19\end{array}$ & $\begin{array}{c}64 \\
3\end{array}$ & 15.27 & $<0.001$ \\
\hline Meetings participation & $\begin{array}{l}\text { Yes } \\
\text { No }\end{array}$ & $\begin{array}{c}67 \\
0\end{array}$ & $\begin{array}{l}50 \\
17\end{array}$ & 26.05 & $<0.001$ \\
\hline $\begin{array}{l}\text { Satisfaction with } \\
\text { Incentives }\end{array}$ & $\begin{array}{l}\text { Satisfaction } \\
\text { Dissatisfaction }\end{array}$ & $\begin{array}{l}56 \\
11\end{array}$ & $\begin{array}{l}44 \\
23\end{array}$ & 5.77 & 0.016 \\
\hline \multicolumn{6}{|l|}{ MARKET } \\
\hline \multicolumn{6}{|c|}{ KRUSKAL-WALLIS TEST } \\
\hline Profitability (\%) & & $169.2 \pm 27.9$ & $97.5 \pm 19$ & & $<0.001$ \\
\hline Incomes per carga (US\$ & per $125 \mathrm{~kg}$ ) & $499.2 \pm 6.9$ & $456.7 \pm 7.7$ & & $<0.001$ \\
\hline \multicolumn{6}{|c|}{ CHI-SQUARE TEST } \\
\hline $\begin{array}{l}\text { Coffee dependence: } \\
\text { Income from coffee }\end{array}$ & $\begin{array}{r}5-40 \% \\
41-80 \% \\
81-100 \% \\
\end{array}$ & $\begin{array}{l}19 \\
25 \\
23\end{array}$ & $\begin{array}{c}30 \\
30 \\
7\end{array}$ & 11.94 & 0.003 \\
\hline $\begin{array}{l}\text { Satisfaction with sale } \\
\text { prices }\end{array}$ & $\begin{array}{c}\text { Satisfaction } \\
\text { Dissatisfaction }\end{array}$ & $\begin{array}{l}46 \\
21\end{array}$ & $\begin{array}{c}61 \\
6\end{array}$ & 10.94 & $<0.001$ \\
\hline
\end{tabular}




\subsubsection{Interaction between drivers}

The CART model (Figure 1) explaining the largest amount of the variance (75\%) in the adoption of organic and conventional schemes of management had five nodes using six location variables (coffee productivity, production costs, number of coffee plots per farm, farm size, type of land owner and technology availability). The results indicated that the most important factor in determining the adoption of organic practices was the availability of adequate technology, since farmers with access to it were $79 \%$ likely to adopt these practices (Terminal Node 3). The type of landowner was the second most important driver since a further split occurred as a result of this factor. With limited access to technology and only one land owner (e.g. head of home, husband or wife), there was $89 \%$ probability of keeping conventional practices (Terminal Node 1). In contrast, farmers with a married couple as owners were $100 \%$ probable of adopting organic management (Terminal Node 2).

In terms of technology, the availability of enough equipment is related to the respective phase of coffee production: growing, harvesting, and processing. Field tools necessary for growing conditions include those aimed for soil preparation with adequate supply of essential mineral elements, seed propagation, planting, fertilisation, shade management, pruning, and weed control. In Colombia, harvesting is a manual selective picking of the ripe coffee cherries and the prevailing mode of processing is the wet process. The latter is a method that requires the use of specific equipment and considerable quantities of water. It is the phase in which the availability of technology portrayed the most significant benefit for farmer labour and time-saving. It involves the use of devices/machinery for classification of fruits, removal of pulp and mucilage from ripe cherries, consecutive drying of washed coffee, and successive screening of beans according to quality principles. After the process, the parchment skin or pergamino is thoroughly dry and crumbly; that will be removed in the off-farm hulling process. Coffee is sold by farmers in parchment to the respective purchase point. 


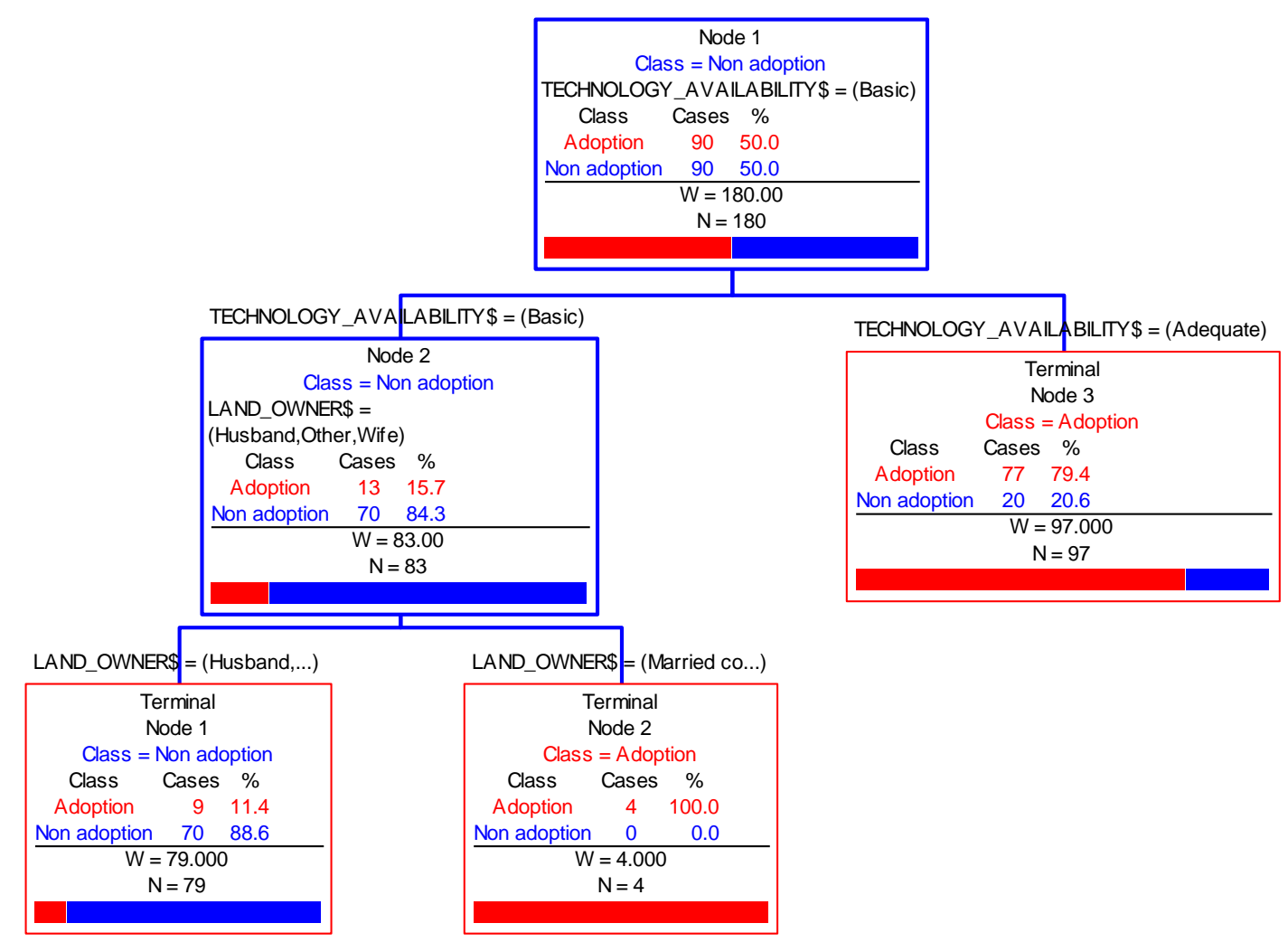

568 Figure 1. CART diagram describing how adoption of organic crops is influenced by location

569 drivers. Each node (square) displays the total number of farmers in that group $(\mathrm{N})$ and the number

570 of growers according to two categories: adoption of organic practices in red, or non adoption (i.e.

571 conventional practices) in blue. The model is read from top down until terminal nodes appear. Tree

572 diagram allows identifying the most important drivers affecting adoption: availability of adequate

573 technology and married couples as land owners in the case of organic management; compared to

574 basic technology and individual owners (husband, wife, other) in the case of conventional

575 schemes. 


\section{DISCUSSION}

In order to improve our understanding of the complex interactions of factors that influence adoption of a coffee management type, an approach that integrates quantitative and qualitative studies was adopted. Survey analysis (quantitative) identified the most significant drivers while ethnographic assessments (qualitative) allowed the contextualization of these drivers within a more in-depth understanding of farmer-farm relationships.

\subsection{Drivers affecting coffee management adoption}

The following drivers were found to be significant determinants of management adoption (Table 2) and their importance is also broadened with information based on ethnographic research.

Years of formal education: More years of formal education were found to influence the adoption of organic farms, which is consistent with studies of Wollni and Brammer (2012) in Costa Rica. Conversely, fewer years were common among conventional farmers. This suggests that farmers with more education tend to be more willing to innovate.

Learning of agricultural practices: Farmers who attend training sessions organised by the coffee institution are more willing to adopt organic management. This indicates that information availability plays an important role (Wollni and Andersson, 2014).

Membership of community organizations: The role of community organizations is key since being part of a collective promotes the adoption of agricultural practices, encourages cooperative working, the strengthening of social networks and the sharing of benefits. Partaking in these collectives indicates the belonging to social networks which have an important role in promoting exchanges of information and resources. This observation is in agreement with Faure et al. (2012) in Costa Rica who show that producers' organizations assume a leading role in certification adoption processes. By comparison in Santander, small farmers' cooperatives are influenced on the selection of certification seals by the coffee institute who also acts as coffee trader.

Compared to results of Geiger-Oneto and Arnould (2011) in Nicaragua, Peru and Guatemala, our study also finds that technical assistance and meetings participation was higher for coffee 
producers who engaged in Fair Trade (FT) collective initiatives than did nonparticipants. However, in our research women participation was noticeably higher than that of men. Further, farmer criteria of better quality of life were common on members of the cooperative whose housing and farms displayed improved physical conditions.

On the other side, it is argued by Geiger-Oneto and Arnould (2011) that the impact of FT organizations may vary across countries. Our results also support and expand it since several factors have influence on the benefit that coffee farmers receive; for example the actor network involved in the process. That network includes in general terms all or a combination of the following: farmers, cooperative of farmers, the coffee institute, a certifier agency, FT inspector, miller, trader, roaster/buyer, retailer, and consumers. Within the network, one of the key roles is focused on the trader, who makes price negotiations, establishes a connection between local cooperatives and a particular roaster, and ensures that the requirements of transport, storage, milling and delivery are fulfilled. That role is deeply rooted in the dynamics of market since it interweaves the interests of growers, processors and buyers/retailers. As such, this strongly influences the amount and type of gains for farmers at local scale.

Availability of technology: Labour saving technology includes machines and implements (Erenstein, 2006) which facilitate post-harvest tasks such as removing coffee beans from the fruit, washing and drying. Adoption can be encouraged if the technology is operator labour-saving (Fernández and McBride, 2002) as may be the case with organic coffee farming.

Land owner: The marital status of farmers is an important determinant of whether organic methods are adopted or not: married couples are more likely to opt for this style of farming. This may be explained by the increased workload associated with organic coffee plantations, especially at the beginning of the crop cycle when a joint effort is required. In the case of conventional farms, only one land owner (e.g. head of home, husband or wife) is the predominant figure who makes decisions regarding farm management. Different studies related to crop adoptions (e.g. Hamadou et al., 2005; Overmars and Verburg, 2005) suggest that land ownership is the most important factor determining organic adoption since it requires significant investment. 
Farm size and coffee plot numbers: In Colombia, 95\% of coffee farming families have less than 5 ha of coffee crop (FNC, 2013a), a circumstance that was found to be particularly common on conventional farms in the study region. Contrary to expectations, organic farms have a greater number of coffee plots and bigger farm areas compared to conventional farms in the study site. Concurring with Weber (2011) in Mexico and Wollni and Brammer (2012) in Costa Rica, it appears that larger growers are more likely to go organic. Small area farmers are less likely to incur the costs of joining a cooperative and converting to organic production; similarly, larger farms are more likely to have the liquidity to afford mineral inputs that can boost productivity and profitability.

Coffee productivity: As with farm size, productivity was found to be higher on organic farms compared to those farmed conventionally. In this study, high productivity was found to be a key factor encouraging farmers to adopt organic methods and there was clear evidence that farmers are motivated by the successes on neighbouring farms. According to previous studies (e.g. Haggar et al., 2011) and results obtained in this study with farmers' perceptions and survey data, high levels of production on organic farms are feasible if certain conditions are guaranteed, e.g. adequate fertilization with natural minerals and organic manure in terms of frequency and amount; shade management according to the age of plantation; frequency of pruning. It can therefore promote local adoption of this management. In accordance with farmers, it should be noted that some research studies (Perfecto et al., 2005; Valkila, 2009; Van der Vossen, 2005) suggest declining yields from organic crops, especially during transition from conventional to organic production.

Production costs, profitability and incomes: The level of coffee profitability, production costs and meaningful incomes were also found to be drivers of management adoption since they can encourage or discourage neighbouring farmers to adopt a management type. The study conducted by Barham and Weber (2012) in Peru and Mexico confirmed that yields rather than price premiums are most important for coffee growers. Farmers are motivated to continue to participate in certified schemes if both the price and productivity improve producer welfare. The local market illustrates the integration of farmers into global trade and market relations which lie well beyond the boundaries of their local agroecosystems. In this regard, $24 \%$ of Colombian coffee exported 
between 2007 and 2012 were specialty coffees with a certification seal, and $69 \%$ were conventional coffees (Muñoz 2012, 2011). Globally, speciality coffees have been estimated to constitute $8 \%$ of world exports and are perceived as having the potential to grow, thanks to greater consumer interest in this type of coffee (ICO, 2013c). Thus, conventionally grown coffees represent a substantial market segment globally (92\%), and a continuous supply is required. The results of this study concur with those of Weber (2011) who studied variations in price received over a season by Mexican Fair Trade organic growers in relation to their cooperative size, product quality, and location. Similarly, Beuchelt and Zeller (2011) describe in Nicaragua that higher farm-gate prices do not lead necessarily to higher per capita net coffee income, as yield levels, production costs, family and land size, as well as labour availability play important roles.

Income from coffee and off-farm job: organic farmers are heavily dependent on coffee farming income, which is interrelated to the total amount of time available for farming and non farming activities. Farmer off-farm employment may constraint adoption of management-intensive organic practices due to it competes for farm managerial time (Fernández and McBride 2002).

Satisfaction with sale prices: a sense of great satisfaction was expressed by conventional farmers compared to organic coffee growers. Our study suggest that this finding may decrease the probability of organic farming adoption given several observations; less time and effort involved in conventional practices compared to organic schemes; substantial reduction on yield especially during the phase of transition to organic management; the time at which survey was conducted coincided with higher and favourable coffee prices.

Institutions: Interviews and observations in the field elicited that the national coffee institute plays multiple roles: it has overall responsibility for Colombia's coffee policy, acts as a trader, conducts coffee research (although organic coffee agriculture receives little attention from research priorities), regulates quality standards for the coffee export market, provides extension programs to farmers, and also over-sees the coffee-growers' guild. It acts at local, regional, national and international levels. 
According to Press et al. (2014), adopting an organic orientation may raise issues of regulatory legitimacy acting at a wide scale. Thus, the economic regulatory structure has had to adapt gradually to the new challenges involved in organic certification processes e.g. input supply, ability of finding a buyer, transportation and storage requisites. Small coffee growers have faced those challenges by the intervention of their trader i.e., the coffee institute.

In our case, that institute also defines legal and procedural requirements with interest in trading specialty coffees, including not only organic coffee. According to field observations, an offer of organic coffee to potential buyers can allow purchasing other certified coffees. In this way, the purpose is to ensure a stock of organic coffee that aids to hook the sale of other specialty coffees. In this instance it is interesting to note that only a minority of specialty coffees is organic i.e., $1.3 \%$ of total cover of coffee land-use in Colombia are organic plantations which contribute $9.5 \%$ to global market (Farfán et al., 2015).

Press et al. (2014) have also highlighted the role of ideological conflicts between organic and conventional farmers as potential barriers to changing management. However, our study finds that these types of tensions are not frequent and thus both schemes of management are perceived as legitimate. More broadly, a tension can take place between affiliated members and non members of the rural cooperative for accessing to a fair distribution of benefits such as training, input supply, and credits.

The role of this institute may be comparable to others such as the Mexican Coffee Institute (INMECAFE) (Eakin et al., 2006) and the Brazilian Coffee Institute (BCI) (Jarvis, 2005). These institutions were government regulated agencies and had overall responsibility for coffee policy and the control of prices. These organizations were abolished in order to limit government action and to allow the market to operate freely.

\subsection{Interaction between drivers}

The drivers described above act simultaneously, and could act synergistically, on decisions regarding the adoption of different management systems. Quantifying the influence of multiple drivers can lead to identification and prioritization of actions and policies to promote organic or 
conventional farming. The CART analysis determined important factors that eventually affect adoption of organic and conventional management, in a sense that although there are many factors that affect adoption decision, there are two which have the most predominant effect when interactions are analyzed; these were: the availability of technology and the type of landowner. It is evident that the availability of technology facilitates post-harvest tasks and it is important to note how this driver interacts with who is the landowner is, e.g. married couples, instead of individuals were common owners on organic farms. This point underscores the role of family in decisionmaking, to continue a particular method of farm management associated with the use of technology.

The use of CART models as a statistical tool to identify interacting drivers has a novel value compared to the reviewed studies of crop adoption. For instance, other studies tested independent factors in the adoption of sustainable agricultural practices by means of multivariate probit models (Ndiritu et al., 2014). Similarly, separated determinants of adoption of conservation farming practices were analysed using tobit and fractional probit models (Arslan et al., 2014).

\subsection{Benefits of combining ethnography and survey methods}

The survey data and ethnographic information revealed that farmers' decision making is influenced by diverse, overlapping and interacting factors. Ethnographic research can thus provide additional information that cannot be quantified or recorder in a survey. For instance, Rueda and Lambin (2013) state elements that define the success of certification schemes in five municipalities of Santander based on both interviews with key informants and a household survey. Such elements entail price premiums alongside training, access to information, technology, social networks, resources, and access to specialty coffee markets. In comparison, our study not only confirms these elements, but also broadens the surrounding context with influence on decision-making process at farm level. This includes the identity of coffee growers associated with place-based ties, the triad of social farming spaces, institutions acting at national and local scales, the social relations of production, plus attitudes about management practices and other farmer factors. It constitutes a more complete frame of reference for understanding the local context in which coffee farmers adopt organic or conventional schemes of management. 
The use of mixed analysis makes visible different views: from an institutional standpoint, seeing landscapes in terms of commodity production can mean that they are treated as isolated entities with extractable units. Thus at regional, national and global levels the treatment of coffee is, as a commodity traded at market, valued for the price it can earn. From farmers' view, coffee agroecosystems are not simply cash crops; it has been fully part of human social life and a piece of local identity.

Ethnographic information from a small sample of farmers in Ocamonte complements the survey data collected from other farmers in Ocamonte, El Valle de San José and Pinchote. For instance, farmers who participated in interviews expressed their dissatisfaction with premiums, prices and low yields on organic crops, especially during transition from conventional systems. In contrast, survey data illustrate higher yields and profitability on organic plantations when the intensity of management is held constant across farms of larger size, and once transition challenges have been overcome. Although the growers' marketing performance depends largely on the quality of coffee produced plus external factors linked to market and certification schemes, this approach combines the strengths of a survey linked to ethnography, allowing a better understanding of coffee farmers' decisions.

The combined analysis of quantitative data (e.g. factors affecting management adoption identified from the survey) and qualitative analysis (e.g. factors identified by the ethnographic study) allows for a more holistic understanding of the local context. The wealth of information generated through the ethnographic viewpoint can also help to explain the results from the quantitative analysis. For instance, population density was found to be low, with even organic farms showing very low values (1.7 \pm 0.3 people/ha) compared to conventional farms $(6.9 \pm 1.3$ people/ha). This situation is related to the migration of farmers' children to urban areas revealing a problematic condition of unusual generational change that is likely to threaten not only the availability of family labour for production and harvesting, but also the continuation of future coffee farming. On the other hand, small-scale farming was found to be predominant on conventional farms (e.g. $1.2 \pm 0.3$ ) ha on 30 conventional farms compared to $4.3 \pm 0.7$ ) ha on 30 organic farms in Ocamonte). This could reflect that coffee farms have become fragmented as they have been passed from parents to children by 
means of property inheritance. Smaller areas may also favour off-farm employment which was found to be higher on conventional farms. Given the high level of interdependence between involvement of family and labour intensity in organic production, off-farm employment may constrain adoption of management-intensive crops (Fernández and McBride, 2002). Thus, it may explain the high dependency on income from coffee yields reported by organic farmers.

Compared with data recorded by other studies (e.g. Eakin et al., 2006; Frank et al., 2011), the use of two sets of data - qualitative and quantitative - provides an improved method with which to achieve a more complete understanding of factors (e.g. social identity, participation in cooperatives) involved in shaping coffee growers' decisions regarding climate change.

\subsection{Policy implications}

\subsubsection{Implications for public policy}

Contrary to generalized perception, our findings suggest that organic practices show important levels of productivity. Thus, we advocate increased and continued support for research and rural extension services into organic agricultural systems, with special attention to different types of mulch and/or manures such as those generated in sugarcane processing. On the other side, given that organic farms utilize different types of inputs, the strengthening of marketing system would be advised in order to ensure constant availability of those that are not produced within the farms (e.g. mineral salts, certified manures). It could support certification norms that promote the improvement of yields which in turn attract and maintain growers on organic schemes.

Driver analysis suggests that the policy of government and donors should focus on investments in the farm and business management skills of coffee growers as well as the strengthening of social programs (e.g., children's education aimed to increase self-esteem as coffee growers). Public support for local cooperatives may be useful in order to avoid potential liquidity constraints since their existence depends heavily on its trade with a particular seal. Thus policy measures can include the enhancement of extension services aimed at supporting price negotiations, opportunities to facilitate technology access and production programs with organic inputs. 
Our analysis shows that adopting organic schemes of management is promoted by multiple drivers at local scale such as high yields, significant price premiums at individual and collective levels, the role of producer cooperatives, availability of technology, and married couples as land owners. At broader spatial scales, despite the fact that there is a trend towards a progressive increase in consumer demand for organic products, the percentage of market that also demands conventional coffees is remarkable. Thus, managers might gain insight from analyzing those drivers of adoption and the cultural context related to identity of coffee growers, overlapping farming spaces, attitudes about management, social relations of production, and the pivotal role of the coffee institute. In the long term, the biggest challenge of coffee grower cooperative is to play a central role in trading coffee.

\section{CONCLUSION}

Our results provide evidence indicating which drivers in the farm scale can affect the adoption of either organic schemes of management or the maintenance of conventional practices. The combination of qualitative and quantitative approaches has proved to be the most appropriate methodology since it enabled the most significant drivers of management adoption to be identified while ethnographic assessment allowed the contextualization of these drivers within a more indepth understanding of farmer-farm relationships. This study provides new insights into the importance of adopting complementary approaches in order to offer a better perspective on coffee production and farmer decisions, since these lie well beyond the boundaries of their local agroecosystems. It clearly emerges that management decisions are not only based on financial factors but on a variety of other circumstances (e.g. identity as coffee growers, the type of landowner, technology, the role of coffee institutions), which are relevant to policy making and development planning. Based on the results of analysis we seek to enrich food certification debates and policy measures that help programs to improve the adoption of certified management schemes. Farmers that adopted organic practices were more educated, included married couples as decision makers, had larger farms with technological tools to facilitate postharvest tasks, and were associated with a cooperative. In line with these findings, organic farms achieved higher 
production levels than conventional coffee farmers. On the other hand, further studies are needed to provide socioeconomic data in years of low, or even depressed, coffee prices to make comparisons of drivers, since those reported in this study were derived from periods when higher and favorable coffee prices prevailed.

\section{ACKNOWLEDGEMENTS}

We are grateful to coffee growers of Ocamonte (APCO), Pinchote and El Valle de San José, the Federación Nacional de Cafeteros de Colombia and their Comités Cafeteros in Charalá, Socorro and San Gil, for orientations, farm access and collaboration. We thank Salford Systems for providing a trial version of CART SPM software. L.B.M. expresses her deepest gratitude to family for immense support and help, CAER and the University of Reading for a pleasant environment of outstanding research, and Colfuturo for significant funding. The authors also wish to thank the highly-constructive comments of the anonymous reviewer.

\section{REFERENCES}

Arnould, E., Plastina,A., Ball, D., 2009. Does Fair Trade deliver on its core value proposition? Effects on income, educational attainment, and health in three countries. J. Public Policy and Mark.28, 186-201. Arslan, A., McCarthy, N., Lipper, L., Asfaw, S., Cattaneo A., 2014. Adoption and intensity of adoption of conservation farming practices in Zambia. Agric. Ecosyst. Environ. 187, 72-86.

Bacon, C., 2005. Confronting the Coffee Crisis: Can Fair Trade, Organic, and Specialty Coffees Reduce Small-Scale Farmer Vulnerability in Northern Nicaragua? World Dev. 33, 497-511.

Barham, B. L., Weber, J. G., 2012. The Economic Sustainability of Certified Coffee: Recent Evidence from Mexico and Peru. World Dev. 40, 1269-1279.

Barham, B. L., Callenes, M., Lewis, J., Gitter, S., Weber, J. 2011. Fair Trade/organic coffee, rural livelihoods, and the "Agrarian Question": Southern Mexican coffee families in transition. World Dev. 39, 134-145.

Beuchelt, T. D., Zeller, M., 2011. Profits and poverty: certification's troubled link for Nicaragua's organic and Fairtrade coffee producers. Ecol. Econ. 70, 1316-1324.

Bolwig, S., Gibbon, P., Jones, S., 2009. The economics of smallholder organic contract farming in tropical Africa. World Dev. 37, 1094-1104. 
Chaves, B., Riley, R., 2001. Determination of factors influencing integrated pest management adoption in coffee berry borer in Colombian farms. Agric. Ecosyst. Environ. 87, 159-177.

Cronon, W., 1985. Changes in the Land Indians, Colonists, and the Ecology of New England. Hill and Wang, New York.

De'ath, G., Fabricius, K.E., 2000. Classification and regression trees: A powerful yet simple technique For ecological data analysis. Ecol. 81, 3178-3192.

Eakin, H., Tucker, C., Castellanos, E., 2006. Responding to the Coffee Crisis: A Pilot Study of Farmers' Adaptations in Mexico, Guatemala and Honduras. Geogr. J. 172, 156-171.

Erenstein, O., 2006. Intensification or extensification? Factors affecting technology use in peri-urban lowlands along an agro-ecological gradient in West Africa. Agric. Syst. 90, 132-158.

Farfán, V., Serna, G, Sánchez, A., 2015. Almácigos para caficultura orgánica: Alternativas y costos. Av. Téc. Cenicafé 0452.

Faure, G., Le Coq, J.F., Vagneron, I., Hocde, H., Muñoz, G.S., Kessari, M., 2012. Strategies of coffee producers' organizations in Costa Rica toward environmental and social certification processes. Cah. Agric. 21,162-168.

Fernández-Cornejo, J., McBride, W., 2002. Adoption of Bioengineered Crops. Agric. Econ. Rep. (810), i-61. Ferraro, D. O., Rivero, D. E., Ghersa, C. M., 2009. An analysis of the factors that influence sugarcane yield in Northern Argentina using classification and regression trees. Field Crops Res.112,149-157.

FNC - Federación Nacional de Cafeteros [Colombian Coffee Growers Federation] (2013a). Nuestros Cafeteros [Our Coffee Growers]. Available on:

[http://www.federaciondecafeteros.org/particulares/es/nuestros_caficultores] Access date: 15 June 2013 FNC, 2013b. An Outstanding Coffee. Available on:

[http://www.cafedecolombia.com/particulares/en/el_cafe_de_colombia/un_cafe_sobresaliente] Access date: 19 October 2013

Frank, E., Eakin, H., López-Carr, D., 2011. Social identity, perception and motivation in adaptation to climate risk in the coffee sector of Chiapas, Mexico. Glob. Environ. Chang. Hum. Policy Dimens. 21,66-76.

Geiger-Oneto, S., Arnould, E., 2011. Fair Trade and producers' quality of life: evidence from the coffee channel, J. Macromark. 31, 276-290.

Guber, R., 2001. La Etnografía. Método, Campo y Reflexividad. Grupo Editorial Norma, Bogotá. Guhl, A., 2008. Café y Cambio del Paisaje en Colombia, 1970-2005. Fondo Editorial Universidad EAFIT, Banco de la Republica, Medellín. 
Haggar, J., Barrios, M., Bolaños, M., Merlo, M., Moraga, P., Munguia, R., Ponce, A., Romero, S., Soto, G., Staver, C., and Virginio, E., 2011. Coffee agroecosystem performance under full sun, shade, conventional and organic management regimes in central America. Agrofor. Syst. 82, 285-301.

Hamadou, S., Kamuanga,M., and Abdoulaye, T., 2005. Factors affecting the adoption of fodder crops in Bobo-Dioulasso (Burkina Faso) peri-urban dairy farms. Tropicultura 23, 29-35.

Handwerker, W. P., 2002. The Construct Validity of Cultures: Cultural Diversity, Culture Theory, and a Method for Ethnography. Am. Anthropol. 104, 106-122.

Hatanaka, M., Bain, C., Busch, L. 2005. Third-party certification in the global agrifood system. Food Policy 30, 354-369.

ICO - International Coffee Organization, 2013a. Botanical Aspects. Available on:

[http://www.ico.org/botanical.asp] Access date: 17 June 2013

ICO (2013b). Exporting Countries: Total Production

[http://www.ico.org/prices/po.htm] Access date: 15 June 2013

ICO, 2013c. Monthly Coffee Market Report - January 2013. Available on: [www.ico.org] Access date: 20 February 2013

Jarvis, L. S., 2005. The rise and decline of rent-seeking activity in the Brazilian coffee sector: Lessons from the imposition and removal of coffee export quotas. World Dev. 33, 1881-1903.

Kottak, C. P., 1999. The New Ecological Anthropology. Am. Anthropol. 101, 23-35.

Lefebvre, H., 1991. The Production of Space. Blackwell, Oxford.

Leve, L., 2011. Identity. Current Anthropol. 52, 513-535.

Mazvimavi, K., Twomlow, S., 2009. Socioeconomic and institutional factors influencing adoption of conservation farming by vulnerable households in Zimbabwe. Agric. Syst. 101, 20-29.

Méndez, V. E., Bacon, C. M., Olson, M., Petchers, S., Herrador, D., Carranza, C., Trujillo, L., GuadarramaZugasti, C., Cordon, A., Mendoza, A., 2010. Effects of organic and Fair Trade certifications on small-scale coffee farmer households in Central America and Mexico. Renew. Agric. 25, 236-251.

Muñoz, L.G., 2012. Caficultura Sostenible. LXXVII Congreso Nacional de Cafeteros 2012. Informe del Gerente General. Federación Nacional de Cafeteros de Colombia. Report available on: [http://www.federaciondecafeteros.org/static/files/IGG2012.pdf] Access date: 8 March 2013 Muñoz, L. G., 2011. Caficultura Climáticamente Inteligente. LXXVI Congreso Nacional de Cafeteros. Presentation available on: [http://www.federaciondecafeteros.org] Access date: 30 November 2011. Ndiritu, S. W., Kassie, M., Shiferaw, B., 2014. Are there systematic gender differences in the adoption of sustainable agricultural intensification practices? Evidence from Kenya. Food Policy 49, Part 1, 117-127. 
Overmars, K.P., Verburg, P.H., 2005. Analysis of land use drivers at the watershed and household level: linking two paradigms at the Philippine forest fringe. Int. J. Geogr. Inf. Sci. 19, 125-152.

Perfecto, I., Vandermeer, J., Mas, A. and Soto-Pinto, L., 2005. Biodiversity, yield, and shade coffee certification. Ecol. Econ. 54, 435-446.

Press, M., Arnould, E., Murray, J., Strand, K., 2014. Ideological challenges to changing strategic orientation in commodity agriculture. J. Mark. 78, 103-119.

Rueda, X., Lambin, E. F., 2013. Responding to Globalization: Impacts of Certification on Colombian SmallScale Coffee Growers. Ecol. Soc. 18.

Stabile, M., Sanders, J., Phillips, T., 1984. New technology introduction in a marginal coffee area of Colombia. Food Policy 9, 245-251.

Steinberg, D., Golovnya, M., 2006. CART 6.0 User's Manual. Salford Systems, San Diego, California. Strand, K., Arnould, E., Press, M., 2014. Tillage practices and identity formation in High Plains farming. J. Mater. Cult. 19, 355-373.

Topik, S., 2008. Historicizing commodity chain, five hundred years of the global coffee commodity chain, in:

Bair, J. (Ed.), Frontiers of commodity chain research, Stanford University Press, pp. 37-62.

Valkila, J., Haaparanta, P., Niemi, N., 2010. Empowering Coffee Traders? The Coffee Value Chain from Nicaraguan Fair Trade Farmers to Finnish Consumers. J. Bus. Eth. 97, 257-270.

Valkila, J., 2009. Fair Trade organic coffee production in Nicaragua-Sustainable development or a poverty trap? Ecol. Econ. 68, 3018-3025.

Van der Vossen, H., 2005. A critical analysis of the agronomic and economic sustainability of organic coffee production. Exp. Agric. 41, 449-473.

Weber, J. G., 2011. How much more do growers receive for Fair Trade-organic coffee? Food Policy $36,678-685$.

Williams, M.M., Davis, A.S., Rabaey, T.L., Boerboom, C.M., 2009. Linkages among agronomic, environmental and weed management characteristics in North American sweet corn. Field Crops Res. 113, 161-169.

Wollni, M., Andersson, C., 2014. Spatial patterns of organic agriculture adoption: Evidence from Honduras. Ecol. Econ. 97, 120-128.

Wollni, M., Brammer, B., 2012. Productive efficiency of specialty and conventional coffee farmers in Costa Rica: Accounting for technological heterogeneity and self-selection. Food Policy 37, 67-76. World Bank, 2009. Designing surveys. Designing household survey questionnaires for developing countries. Available on: 
961 [http://econ.worldbank.org/WBSITE/EXTERNAL/EXTDEC/EXTRESEARCH/EXTLSMS/0,,contentMDK:21555

962 919 menuPK:4196884 pagePK:64168445 piPK:64168309 theSitePK:3358997 isCURL:Y,00.html] Access

963 date: September 2009

964 York, R., 2012. Residualization is not the answer: Rethinking how to address multicollinearity. Soc.

965 Sci. Res. 41, 1379-1386.

966 Zheng, H., Chen, L., Han, X., Zhao, X., Ma, Y., 2009. Classification and regression tree (CART) for

967 analysis of soybean yield variability among fields in Northeast China: The importance of phosphorus

968 application rates under drought conditions. Agric. Ecosyst. Environ. 132, 98-105.

969

970 SUPPORTING INFORMATION

971 Additional supporting information may be found in the online version of this article:

972 Appendix A. Questionnaire used on coffee grower homes in relation to coffee agricultural 973 practices, productivity and land uses.

974 Appendix B. Driver screening: Fifty drivers categorized into social, labour, environmental, 975 institutions and market categories.

976 Appendix C. Fifteen combinations of drivers analysed by CART models using information from 67 977 organic and 67 conventional farms. 